\title{
Mechanisms Unfolded by the Media for the Spectacularization of the Public Sphere Represented in José Ricardo Morales' Play Cómo el poder de las noticias nos da noticias del poder (1971)
}

\author{
Juan DEL VALLE ROJAS, PhDc \\ Department of European Languages and Cultures \\ Faculty of Arts - Graduate School for the Humanities \\ University of Groningen, Netherlands \\ E-mail: j.a.del.valle.rojas@rug.nl
}

\begin{abstract}
This work presents a brief theoretical conceptualization of the complexities of the mechanisms unfolded by the media for the spectacularization of the public sphere presented in José Ricardo Morales' play Cómo el poder de las noticias nos da noticias del poder $(1971)^{1}$. It focuses on the following research question: What specific complex discursive-based power strategies related to the spectacularization of the public sphere in the media can be identified in José Ricardo Morales' play? In this article, my final goal will be to emphasize Morales' capacity to predict the use of different mechanisms of spectacularization of the public sphere, carried out by the corporate media and politicians to seize information and, consequently, influence the audience's decisions and preferences on television.
\end{abstract}

Keywords: José Ricardo Morales; Cómo el poder de las noticias nos da noticias del poder; Spanish Modern Theatre; Spectacularization of the media; Public sphere.

1 A suitable English translation of the play can be: How the power of the news can give us news about the power. Translation belongs to the author of this paper. 


\section{Introduction}

This paper aims to address the following research question: What specific complex discursive-based power strategies related to the spectacularization of the public sphere in the media can be identified in José Ricardo Morales' play Cómo el poder de las noticias nos da noticias del poder (1971) ${ }^{1}$ ? As an approach to the understanding of Morales' conceptualization of the media manipulation, I have traced one recurrent problematization node in Morales' works, specifically in the abovementioned play: the complexities of the mechanisms unfolded by the media for the spectacularization of the public sphere. This conceptual challenges span Morales' intellectual and artistic production.

In the context of the findings presented in this chapter and the specificity of Cómo el poder de las noticias nos da noticias del poder (1971), my analysis will be informed by the following theoretical framework: I will draw on theoretical input in the studies on the role of sensationalism in the media and studies on entertainment television (Adorno and Horkheimer, 1993; Bourdieu, 1998; Hendricks, Nuijten, and Beentjies, 2005; Ahern and Sosyura, 2015; Ge, 2016; and Deuze and Witschge, 2018). In addition, I will draw upon theories on the role of the media as a political tool of government and the use of affinity by politicians to convince their audience (Benson and Neveu, 2005; Littlejohn and Foss, 2009; Mosco, 2009; Turow, 2009; Bolin, 2014; Manning and Holmes, 2014; and Van Aelst and Walgrave, 2016).

Morales' capacity for problematizing media manipulation, specifically on television, contributed to the creation of a parallel narrative of possible futures both defying national literary canons and anticipating several issues related to media intervention by corporate media and politicians in the 1960s and 1970s. Likewise, it is relevant and beneficial for the understanding of the process of evolution and intervention of media manipulation not only in Chile but around the world. Considering that José Ricardo Morales conceived theatre as an agent of social change, the purpose of this article, apart from analyzing the discursive-based power strategies in Morales' play, it also aims at identifying specific topics that may be included in the teaching-learning process of the secondary education program provided by the Ministry of Education of Chile. By doing this, the topics would be incorporated as complementary material for the achieving of the Learning Goals of the secondary education Study Program -the instrument that helps to orientate and organize the pedagogical work during the academic year, which is suggested by the Ministry of Education of Chile. Those Learning Goals (Objetivos de

1 Morales, J. (1971). Un marciano sin objeto / Cómo el poder de las noticias nos da noticias del poder. Santiago of Chile: Editorial Universitaria. 
Aprendizaje), which describes the goals that students must get at the end of each of these Units, are key to promote an interdisciplinary work in the courses of Language, History and Literature, focusing on the role of the media in society through a theatre play.

In what follows, I will analyze these extracts which deal with the representation of media practices whose main purpose is to build an intertwined relationship between private and public interests and the distortion of reality provided by journalists (Valdivia, 2014).

\section{Theoretical framework}

José Ricardo Morales (1915-2016) was a Spanish-Chilean playwright and writer on both sides of the Atlantic who established the classic tradition coming from Renaissance humanistic features in his plays, and contributed to the professionalization of the theatre in Chile as well. Regarding his contribution to the Chilean theatre, Morales promptly got involved in the Chilean cultural field and brought broad experience of theatre in Spain expressed both in his dramatic creation and participation in theatre groups (Ahumada \& Godoy, 2002, 125). Likewise, Morales co-founded the University Theatre (1941) which later became the National Theatre of Chile. In this regard, Morales launched his avant-garde aesthetical theatre challenging the local literary canons in Chile in which he anticipated the several problems we are now facing in society, such as the issues of media manipulation, totalitarianism, globalization, and technology dependency.

\section{A brief summary of the play}

This play addresses the use of misinformation and fake news in the media. More specifically, it develops the topic of the intertwined power between politicians and journalists to create false information to control absolute power. The main characters are: El Periodista (The Journalist), the representative of the media who interviews a professional fashion model in a television programme (he intentionally constructs a stereotypical gender role on television: A young woman consuming soap operas) and helps the Minister to become the president of the country; El Ministro (The Minister), the representative of the government who is running for the presidency along with the help of the Journalist in order to establish an unconstitutional totalitarian monarchy; and La Reina de los Balnearios (The Queen of the Spa), the professional fashion model who is interviewed by the Journalist. At the beginning of the play, the Minister is presented as a politician who uses television as a political device to convince the audience to vote for him in the presidential elections and the Journalist helping him to become the chronicler of the future presidency. Parallel to this event, the Journalist is interviewing the character of the Beauty of the Spa, who is presented as a figure of exhibition- 
ism, eroticism, and vanity in sexist advertising. Accordingly, the Journalist uses the interview as a device of distraction to entertain the audience. As the Minister is interested in the Journalist's capacity to manipulate the audience, they agree to work together for the candidacy to the presidency. In return, the Journalist would be named as the chronicler of the presidency. Then, the Minister wins the presidency. However, both are sent to jail and the Minister decided to remove the Journalist as a chronicler. Finally, in response to that, the Journalist gathers all the journalists and convince them that he should be the next president so that they need to overthrow the Minister's presidency arguing that people who control the information must control the country.

\section{Spectacularization of the public sphere}

In this regard, I will focus on the understanding of the complex discursivebased power strategies presented in José Ricardo Morales' play Cómo el poder de las noticias nos da noticias del poder (1971). Hence, the following analyses will highlight Morales' capacity to predict the use of different mechanisms of spectacularization of the public sphere, ${ }^{2}$ carried out by the corporate media and politicians to seize information and, consequently, influence the audience's decisions and preferences on television. The result is the arising of sensationalism in the media provoking emotional reactions in the audience (Ge, 2016). I will focus on key theories by scholars regarding the use of affinity and friendly discourses on television and the use of sensational news by politicians to manage emotions of the audience benefitting from space given in the media and, on the other hand, the media increasing profits in the marketplace.

Back in the 1970s, the previous studies on the history of communication became interested in the new method of exploring communication and journalism, that is, the media studies and all the other related fields and research areas. More

2 According to Littlejohn and Foss, public sphere is central to the study of public discourse, political communication, and deliberative democracy. In their work Encyclopedia of Communication Theory (2009), they make a distinction between private and public sphere in which they mention that the origin of the idea of the public sphere comes from ancient Greece, where it was opposed to the private realm (household, home, and family). Hence, private realm was not considered to be protected from institutional power. On the other hand, the public realm included freedom, politics, and action. In this context, it was a "space of appearance where one could be seen and be heard by other humans". It is precisely that presence of the other and the plurality of agents that constitute the public realm (814). For further information, see: Arendt, H. (1998). The Human Condition. Chicago, IL: University of Chicago Press; Habermas, J. (1974). The public sphere: an encyclopedia article, New German Critique, 3: 49-55; and Habermas, J. (1989). The structural transformation of the public sphere. An inquiry into a category of Bourgeois society. Cambridge, MA: MIT Press. 
specifically, this different view of communication brought about new research fields such as popular culture and class and gender representations on television (Simonson et al., 2012, 31). Considering the particular field of television between the 1980s and 1990s, there was a huge change in the media landscape: the proliferation of autonomous and private television companies leading to a new era of television, the neo-television era (Eco, 1990). In addition to that, public and private television started using diverse strategies for increasing audience and making a profit from advertising. Hence, television companies increased the broadcasting of entertainment television programmes such as game shows, talent shows, dating shows, and quiz shows to the detriment of informative and cultural programmes (Moreno-Díaz \& Medina, 2017). Since then, scholars started researching entertainment television as it reflected the popular culture which is essential for the understanding of the world (Croteau \& Hoynes, 2014). In line with this, they envisaged using entertainment media and sensational news by politicians and corporate industry as a powerful mechanism of social control to impose their worldview. Therefore, the corporate media, in order to avoid people's perception of negative political issues such as corruption and mismanagement of public resources, started to use all those mechanisms of spectacularization to convince and, consequently, increase audience numbers. In other words, the beginning of commercial television led to an interest in converting television into a profit marketplace following a capitalist agenda resulting in the spectacularization of the media and society (Croteau \& Hoynes, 2014).

In accordance with the concept of spectacularization mentioned above, the experts in semiotic and communication studies David Chandler and Rod Munday, in their work A Dictionary of Media and Communication (2011, 403), pointed out that the term spectacularization refers to the "the process of producing a representation in the form of a major spectacle". Accordingly, spectacularization is the exaggeration of the contents presented on television as argued by Chandler and Munday in the case of "commercial television with extravagant budgets and visual effects" (Chandler and Munday, 2011, 403). In this sense, it can be stated that entertainment television programmes develop this spectacularization of the contents to attract the audience by connecting their contents and programming activities with reality making the public be convinced they can look like and feel like people appearing on television. Consequently, spectacularization was acting as an ideological discursive strategy promoting a false and, at the same time, perfect construction of reality (neglecting reality in itself) to the audience through subjugation to miscellaneous programs (Berardi, 2013, 695). 


\section{The Chilean context}

In the context of the spectacularization on television in Chile, a suitable example of this can be traced in Leda Berardi's (2013) studies on the analysis of several Chilean TV programmes containing symbolic violence in which she argues that the television show is a ludic and dreamy simulation of concealing reality. She concludes that symbolic violence on television derives from discrimination against people who both do not fit certain canons of beauty imposed by today's society and are excluded from certain socio-economic sectors. In order to exemplify her theory, Berardi analysed the famous entertainment television programme Yingo (2007-2013) in which appeared a couple of young women dancing disguised as Barbie dolls and celebrities at the beginning of the show. This situation, she adds, "established the myth of object woman and naturalizes their condition as an erotic object according to the American standards of beauty". Regarding this, Berardi $(2013,691)$ concludes that those performances on television "constituted an essential basis of ideology underlying in every spectacle which naturalizes and objectifies women as erotic and seduction objects".

\section{Analysis of Cómo el poder de las noticias nos da noticias del poder (1971)}

In the following sections, I will assess that Morales represents in three passages of his play the use of different mechanisms of spectacularization presenting egocentric and friendly discourse by the media, as well as its mutual dependency with politicians to control the information circulating in the public sphere through television. After that, I will demonstrate how Morales represents this spectacularization of the media in his play as the use of sensational news in the newspapers and television.

\section{Analysis 1:}

\section{Egocentrism and friendly discourses as mechanisms of spectacularization}

In Cómo el poder de las noticias nos da noticias del poder (1971), Morales reveals the egocentric discourses used by politicians in the media as a political instrument to convince and persuade the citizenship as in the representation of the character of the Minister convincing the audience that he is a suitable person to become president of the country due to the fact that he has heard an inner voice claiming for it. These egocentric discourses are supposedly aimed at preventing citizens from gaining the truth and, consequently, perpetuate power in the government according to the Minister's plan of converting the presidency into an "unconstitutional hereditary monarchy":

THE MINISTER arrives. THE JOURNALIST comes close to him. They warmly greet each other. The group of artists repeats it in a whisper: I, I, I.... THE JOURNALIST: - Mister Minister! 
THE MINISTER: - My friend!

THE JOURNALIST: - Is it true the rumor?

THE MINISTER: (After thinking carefully). - Do you mean that vague murmur saying something like I, I, I?

THE JOURNALIST: - It's heard, indeed.

THE MINISTER: (Alarmed). - So, don't tell anyone!

THE JOURNALIST: - I'll keep the secret.

THE MINISTER: - In the name of the professional ethics.

THE JOURNALIST: - You can count on me.

THE MINISTER: - Since I was a child I've heard this rumor saying I, I, I, I, I, I.

(Murmur of the artists is increasing). Can you hear it?

THE JOURNALIST: - Probably, it is a buzzing in your ears [...]

THE MINISTER: - No. No. It comes from the very inside. A psychiatrist told me that it is because of a concomitant of my superego with the paternal-maternal hereditary complex by mouth.

THE JOURNALIST: - Certainly.

THE MINISTER: - But don't tell it.

THE JOURNALIST: - When hasn't a journalist kept a secret?

THE MINISTER: - You're right. So, don't tell that I aspire to run for the Presidency.

THE JOURNALIST: (Surprised) - So, it is true the rumor...

THE MINISTER: - Which one?

THE JOURNALIST: (Evading). - The artists say: "I, I, I".

THE MINISTER: - Ah, well (Pause). So, don't tell that I aspire to become my presidency in a anti-constitutional hereditary monarchy.

THE JOURNALIST: - I'm dumb.

THE MINISTER: (Deciding). - I offer you far more! You'll have the scoop! You'll have the scoop, exclusivity!

EL PERIODISTA: (Exalted). - So, let's make news! Mister Minister, I'm all ears. (Morales, 1971, 74-75-76. Translation belongs to the author of this research).

In this extract, Morales conceptualizes the way politicians use egocentric discourses in the media as a political tool used by the government for persuading the audience presenting false information as in the case of this excerpt where the character of the Minister tries to convince the audience to vote for him to be the next president (Littlejohn \& Foss, 2009). It also illustrates the Minister's lack of shame, guilt, and empathy as demonstrated in the passage where he is aiming at becoming president in order to exchange it for political favours and actions. Moreover, what is important to emphasize here is Morales' representation of egocentrism in the excerpt when the Minister responds to the Journalist that he has heard an in- 
ner voice saying "I" since he was a child. It is clearly representing the politicians' egocentrism when pursuing power.

Politicians and corporate media seek absolute control of information in the media including people producing information whilst using it as a mechanism of spectacularization of the public sphere regardless of the quality of the information. In other words, the media intervene in the public sphere, that is, in the locus of action gathering diverse visions of society where citizens come together, in order to sell the products (entertainment television and advertising) that will make them earn profits (Fortner, Snesareva \& Tsitovich, 2014, 326). Going further, this use of different mechanisms of spectacularization in the media deals with the political economy of the media whose basis is sustained in the political-economic structure in the journalistic field. According to Vincent Mosco $(2009,2)$, political economy can be understood as the study of the social and power relations that "constitute the production, distribution, and consumption of resources, including communication resources". In line with this, Mosco (2009) states that both politicians and corporate industry master economic and material property in order to oversee the contents of the media, that is, the complete control of the journalistic field.

\section{Analysis 2:}

\section{Affinity and common sense in political discourse within the media} as mechanisms of engaging the audience

Regarding the use of mechanisms by the media to manipulate the viewers, Morales' play focuses on affinity and common sense rather than political strategic language as a mechanism used by politicians to be close to the audience. The following extract presents the character of the Minister explaining to the audience that he is the suitable politician for assuming the Ministry of Culture as he was the former Minister of Agriculture. In that regard, the Minister ironically convinces the audience that he already knows about culture because it is the "prelude to agriculture" since the word culture fits in other word agriculture avoiding the use of two more syllables. This is how he had been rigorously preparing for assuming the different ministries during his career as minister:

THE MINISTER: - Provided that those coming from one side don't come out from the other. (THE JOURNALIST agrees). Do you know why I accepted the Ministry of Culture?

THE JOURNALIST: (Amazed). - Are you going to reveal me the great secret that stirs public opinion?

THE MINISTER: - Indeed. You think with me: Does exist a better preparation for culture than agriculture?

THE JOURNALIST reflects on that. Look at THE MINISTER and smile. THE MINISTER smiles. THE JOURNALIST smiles. THE MINISTER smiles. A laughter of 
THE JOURNALIST. Another one of THE MINISTER. Extended laughters of THE JOURNALIST and THE MINISTER that infects mutually. The laughter declines. A smile of THE JOURNALIST. Another one of THE MINISTER. Silence.

THE MINISTER: (slightly embarrassed) - What do you think of that argument?

THE JOURNALIST: - Irrefutable. Agriculture is the prelude to culture. And this is how you changed the Undersecretary of Transportation for domestic economy, and from that to nuclear research, and then move on to mother's care?

THE MINISTER: - Yes. This is how I was rigorously preparing for the different ministries.

THE JOURNALIST: - Can you explain how?

THE MINISTER: - Very simple. Due to agriculture comfortably fits in culture and even you save two syllables.

THE JOURNALIST: - Fantastic! This way typists, typographers, presenters and farmers work less... (Morales, 1971, 76. Translation belongs to the author of this research).

In this extract, Morales explores the irreverent designations of different ministers taking part in the government using nonsense explanations as a political strategy about the role of the Minister of Agriculture in the dialogue "agriculture is the prelude of culture". Morales problematizes the influences in the choice of politicians as a strategy of perpetuation in power in terms of gaining access and favourable coverage in the media and, at the same time, promote events according to their own interests (Van Aelst \& Walgrave, 2016). The Minister's answers are intentionally selected by him to establish certain emotional connection or affinity with the Journalist and the audience in order to be perceived as an ordinary person using colloquial expressions and basic explanations about certain topics, that is, a politician who can be close to them sharing his wishes, dreams, etc. Certainly, the character of the Minister takes advantage of the power of television to promote popular myths to impose his beliefs as demonstrated in his nonsense explanation about the choice of the Ministry of Culture and then Agriculture ${ }^{3}$ where he then grossly and ironically explained that he was prepared to assume as "Minister of Culture" because "Culture was the prelude of Agriculture".

In this passage, the Minister is using irony since he is searching for affinity with the audience. According to the experts in political sociology Manning and Holmes $(2014,709)$ "affinity is a concept that draws attention to democratic equality and

3 This humorous interplay between culture and agriculture in Morales' play could be connected to the incident of Perón trying to transfer the famous Argentinian writer Jorge Luis Borges from his position as Librarian to "Inspector de aves, Conejos y huevos". For further information, see <https://www.perfil.com/noticias/cultura/borges-inspector-de-avesy-detective.phtml>. 
calls for politicians to share things -or at least perform a connection- with 'ordinary' people and everyday life", contrary to the old view that politicians should use several skills and knowledge to make them competent representatives. In their study on affinity related to politics, they argue that affinity is used by politicians to "include a location, a way of speaking, comportment, attitude, particular values or experiences" (Manning and Holmes, 2014, 709). This means that politicians create a kind of image of a charismatic and humble person on television that allows them to be close to the citizens. This representation on television of politicians as ordinary people is problematized by Morales' play in order to attract and convince the audience.

In the following analysis of the excerpts from Morales' play Cómo el poder de las noticias nos da noticias del poder (1971), I will discuss the commercial interest behind the production of sensational news on television operating as mechanisms of spectacularization of the public sphere.

\section{Analysis 3:}

\section{Sensational news as mechanisms of spectacularization}

Regarding the use of spectacularization in the media presented in Morales' play, an important fact is the production of sensational news in newspapers and television in order to make a profit from advertising. In this extract, the Minister is supposedly focused on the injustice occurring to one of the artists participating in the TV program who has not received any award during his career as an artist. Although he seems to be interested in the career of an unknown artist, he is also taking advantage of the situation to be seen as a politician who is concerned about people. Undoubtedly, this is a mechanism of spectacularization to create sensational news and, consequently, increase the audience:

THE MINISTER: - You interpret me. And culture effortlessly includes childcare, fish farming, horticulture and sculpture.

The artists' choir exclaims, surprised: Sculpture! The artists jump over THE MINISTER.

THE FAT ARTIST: - Are you talking about culture?

EL PERIODISTA: - Mister Minister just mentioned it.

THE SLIM ARTIST: - Don't forget that I was awarded by the Art Biennale of Venice.

THE TALL ARTIST: (Interrupting the conversation). - I have honorable mention of my two surnames in Sao Paulo.

THE FAT ARTIST: - I'm first medal for religious art in Lourdes and Fatima [...]

THE MINISTER: - Continue, continue.

THE SHORT ARTIST: - And so on.

THE MINISTER: - Why don't you describe your prizes? 
THE SHORT ARTIST: - My own modesty prevents me from claiming that I don't have any prizes.

THE MINISTER: - How is it possible?

THE SHORT ARTIST: - As you heard.

THE MINISTER: (Astonished). - An artist with no prizes!

THE SHORT ARTIST: - The only one!

THE MINISTER: - An exceptional human being! The most misunderstood! I promise to repair injustice immediately. Let's constitute the panel: the Ministry of Culture, a representative of the press and a delegate of the artists. (Morales, 1971, 78. Translation belongs to the author of this research).

In this passage, Morales problematizes the commercial interest in the production of sensational news in the media. Within news production the role of the journalist is to report what is already there, which implies a construction and selection of social reality to produce stories according to the event he/she is investigating (Hjarvard, 2012, 88). However, if we consider what was sustained above, news finally produces a distorted view of the world. Furthermore, when it comes to the production of news considering the spectacularization of the events to attract the audience, news production is more likely to belong to the manipulation of the news to get people interested in the events regardless of the quality of the information than the impact it may have on the audience.

From an economic point of view, if we consider the media as a product of exchange, it engages in four different markets to produce the news: advertising market, in which news media attract the attention of the news audience for money from the advertisers. It can be found in the excerpt of the Minister emphasizing the necessity of creating an award ceremony on behalf of the artist who did not have prizes; audience market, in which news media deliver information and entertainment to increase audience numbers, who, in return, deliver both money and attention. This market can be connected to the Journalist and Minister's idea of emphasizing the artists' prizes to entertain the audience where Morales is clearly critiquing the commercialization of the arts; the market of news sources, in which news media deliver attention to sources who, again, provide the raw material of news: information. This can be related to the artists when giving information to the Minister about the prizes won abroad; and owners markets, in which owners invest money in the news business in order to gain a profit. It is present all over the play (McManus, 1994, 60; Hjarvard, 2012, 92).

As outlined above, the media industry, in which editorial processes are influenced by commercial and political pressures, is then interested in the coexistence of commercial and political press to gain higher circulation among the commercially attractive audience (Herman \& Chomsky, 1988). By doing so, it gives way to the emergence of sensational news production. According to communication 
scholars Hendricks, Nuijten and Beentjies (2005, 282), sensationalism corresponds to "a [market-driven] journalism with a generally low informational level and a homogeneous content, directed primarily at those sections of the population that are most interesting to the advertisers". In general terms, journalism studies define sensationalism as a "sign of declining journalistic standards" affecting democratic societies including sensational topics focused on emotions rather than information such as show business and game shows, such as the inclusion of socially insignificant stories in entertainment television (Ge, 2016, 22).

This passage may be seen as a critical approach to the concept of news value, that is, a system of criteria which journalists must follow in order to decide about the inclusion or exclusion of material in the reporting of the news (Hjarvard, 2012). In this sense, Morales problematizes the emergence of sensational and entertainment television as is demonstrated in the characters of the Journalist and the Minister who are more interested in generating and spreading sensational events to increase their audience than focusing on the quality of the discussion with the artists participating in the TV show. Here, Morales is problematizing the way television included sensational news and events in the 1970s in order to promote entertainment rather than informative television programs to maximise audience numbers which could make television a profitable market for the corporate industry. In other words, the production of news is attached to a commercial logic: the more they sell or increase ratings, the more profit could be made (Fortner, Snesareva \& Tsitovich, 2014, 318).

Moreover, this extract reveals that both the Journalist and the Minister are interested in the exception that could be a meaningless issue for the audience (an artist with no awards). However, they are interested in something that breaks the routine in order to create a sensational piece of news and, consequently, attract viewers (Bourdieu, 1998). Moreover, the Minister's decision of helping the artist can also be considered as populist as it seeks to satisfy and be approved by the audience which, in this time are turned into commodities. As argued by Adorno and Horkheimer $(1993,33)$ "the result is the circle of manipulation and retroactive need in which the unity of the system grows ever stronger". In this regard, the scholars Ahern and Sosyura $(2015,2050)$, in their research on the use of sensationalism in the media, argue that "the business press plays a key role in capital markets as a distributor of information" which, in order to gain audience or readers (in the case of the newspapers), "have an incentive to publish [broadcast] sensational stories, namely attention-grabbing, speculative news with broad readership [viewers]". The goal of corporate media is, then, make these speculative stories impact asset prices.

As stated previously, Morales' play reveals the tricks used by journalists, politicians, and business actors (advertisers) in order to take advantage of the media 
through subliminal advertising as in the excerpt of the Minister offering the award of the artist who did not have any prizes in his career. This means that the market influences the news as long as the media becomes more popular by means of sensationalist news, entertainment, and populist politics producing the rise of public criticism and intervention on television (Hjarvard, 2012, 91). This reciprocal relationship is part of a triad that is set by the media companies, advertisers and the audience, as clearly stated by Vincent Mosco $(2009,137)$ "whilst the media constructs the audience, advertisers pay media companies for access to these audiences resulting in the audiences being delivered to advertisers".

To conclude, I provide a brief discussion of the analysis of the excerpts from Morales' play Cómo el poder de las noticias nos da noticias del poder (1971) with the mechanisms of spectacularization of the public sphere used by the media such as the use of egocentric and friendly discourses and sensational news.

\section{Discussion}

In the previous section, I discuss how Morales' play reflects on the relationship between the government and the media when showing the close and dependent relationship in the characters of the Journalist and the Minister who attempt to perpetuate power (Azcue, 2014). This is an important issue as we have currently been facing the emergence of corporate media in entertainment television which follows a process of commodification of the media workplace resulting in a process of manipulation of the content decisions influenced by the political pressure to the corporate media (Deuze \& Witschge, 2018). Considering that the main function of mass communication, apart from educating and informing, is entertaining, it determines that this role of entertainment is used by the media to divert attention from central focus of important issues to the public (Shaw \& McCombs, 1977). Therefore, it is not that surprising to state that the ultimate role of the media is to entertain the audience. But what seems to be relevant is the following marketization of television that has led to a "close relationship between journalists and politicians resulting in entertainment logic of television" (Bolin, 2014, 337). Regarding content issues on television, Turow $(2009,540)$ argues that "it is the industry's commercial motives, and the resulting commodification of its audience, that has led to what they [critics of the U.S. television industry] consider programming that emphasizes violence, sex, and sensationalism at the expense of quality". According to the one of the purposes of this article regarding the relevance of Morales' play in education, this topic of marketization of television following entertainment logic to divert attention from important issues to the public may be useful to incorporate into the teaching-learning process in secondary education in Chile. In particular, the topic can be discussed as complementary material in the teaching of Language and Communication course in first grade considering the involving the explanation with 
examples of several strategies of persuasion used in an advertising message and propaganda. In particular, this theme can be useful to develop the Learning Goal 10 of the first grade (secondary education) Language and Literature Study Program which challenges the students to analyze and evaluate texts of the media such as news, reports, letters to the editor, propaganda or chronicles

We have discussed Morales' critique of the use of mechanisms of spectacularization in the media for both politicians and corporate media's own benefit when controlling the information on entertainment television in order to convince the audience about political agenda. This spectacularization could be linked to the theory of the Society of Spectacle developed by French philosopher Guy Debord (1992) defining spectacularization in several media formats and genres divided into information (hard news) and entertainment (soft news). In line with this, he concludes that in recent times, this difference between information and entertainment is unclear both for the audience and journalists (Debord, 1992; Montero \& Ferré-Pavia, 2017). Later on, Lipovetsky and Serroy (2008) established that this information is part of the consumer society and entertainment media companies. Therefore, entertainment media produces specific language to build up information in order to make people feel all the information they are consuming is immersed in a never-ending show (Montero \& Ferré-Pavia, 2017, 37).

In Morales' play, there is evidence of the way politicians and corporate media agree to produce a TV quiz show resulting in a program where there is uncertainty about the purpose of it. This means, the TV quiz show represented by Morales describes the combination of entertainment and information on television as it is presenting the character of the Minister informing the audience about the trees and forest in the celebration of the Tree Week but, at the same time, using nonsense answers and colloquial language to entertain and be close to the audience.

\section{Conclusion}

As argued above, Morales's play may be useful to cover several Learning Goals in the course of Language and Communication in secondary education. Specifically, it serves to promote the interdisciplinary teaching of several topics related to the media manipulation and the objectification of women on television represented in a theatre play in the courses of Language, History and Literature.

In this article, I discussed the use of distinct mechanisms of spectacularization by the media industry to control the information. I highlight the role of television in producing sensational news and focusing on entertainment television programmes as can be seen in the passage of Morales' play when the Minister appears on television generating a sense of caring for the citizens at the time he is actually seeking voters for his presidential candidacy. In addition to that, this reflection of the Chilean context is connected to what Manuel Martín Serrano (2004) and 
Christian Fuchs (2009) explain about the strategy used by politicians -supported by corporate media- to extend the audience's valorization and legitimization whilst preserving determined cultural patterns reproducing social domination structure in society to perpetuate power. For the Chilean context, Morales problematizes the use of emotions and affect as discursive strategies by politicians on television to attract and convince the audience of supporting them. Notwithstanding, there are two other discursive strategies that are currently used as mechanisms of spectacularization of the public sphere which Morales did not consider in his play: the use of honesty and strong character by television personalities. In line with this, it could be worth further researching the arising of those celebrities on television whose discursive strategies are used to threaten their colleagues on television using those polemic phrases such as 'nobody gets involved with me', 'I always say what I think' or 'do not mess with me or I am going to destroy your career'- and, at the same time, to be accepted by the audience.

Regarding power relations in the corporate media, Morales' play reflects on the media industry becoming a private institution sharing plural information to a broad audience following a business logic which is measured by their ability to "command advertising revenue" with the purpose of ensuring that media can be a "business success" (Arsenault \& Castells, 2006, 301). Even though Morales' play contributes to the understanding of the business logic of the media, it did not consider the commercial involvement of television in heterogeneous spaces reaching most of the population since it was written before the advent of social media and the irruption of new hegemonic technological devices. Hence, I consider necessary to explore the role of corporate media in society paying special attention to how this era of new technologies and social media interfere with the public sphere.

\section{References}

1. Adorno, T. \& Horkheimer, M. (1993). The Culture Industry: Enlightenment as Mass Deception. In S. During (Ed.). (1999). The cultural studies reader (2nd ed). London; New York: Routledge.

2. Ahern, K. R., \& Sosyura, D. (2015). Rumor Has It: Sensationalism in Financial Media. The Review of Financial Studies, 28(7), 2050-2093. doi: 10.1093/rfs/hhv006.

3. Arendt, H. (1998). The human condition (2nd ed). Chicago: University of Chicago Press.

4. Arsenault, A. \& Castells, M. (2006). Conquering the minds, conquering Iraq: The social production of misinformation in the United States -a case study. Information, Communication \& Society, 9(3), 284-307. doi: 10.1080/13691180600751256.

5. Ahumada, H., \& Godoy, E. (2002). Un dramaturgo al trasluz: José Ricardo Morales. Revista Chilena de Literatura, (60). Retrieved from: https://revistaliteratura.uchile.cl/ index.php/RCL/article/view/1728/1598. 
6. Azcue, V. (2014). El estreno de La adaptación al medio y Cómo el poder de las noticias no da noticias del poder de José Ricardo Morales, por el Grupo Ercilla. Laberintos, 16, 215-225.

7. Benson, R. \& Neveu, E. (2005). Bourdieu and the Journalistic Field. Cambridge, UK: Polity Press.

8. Berardi, L. (2013). Violencia simbólica en programas juveniles de televisión abierta en Chile. Discurso \& Sociedad, 7(4), 685-698.

9. Bolin, G. (2014). Television, Journalism, Politics, and Entertainment: Power and Autonomy in the Field of Television Journalism. Television \& New Media, 15(4), 336349. doi: 10.1177/1527476414525671.

10. Bourdieu, P. (1998). On Television. New York: New York Press.

11. Chandler, D. \& Munday, R. (2011). A Dictionary of Media and Communication. Oxford: Oxford University Press.

12. Croteau, D. \& Hoynes, W. (2014). Media/Society: Industries, Images, and Audiences (5th ed). Thousand Oaks, CA: SAGE Publications.

13. Debord, G. (1992). La société du spectacle. Paris: Éditions Gallimard.

14. Deuze, M. \& Witschge, T. (2018). Beyond Journalism: Theorizing the transformation of journalism. Journalism, 19(2), 165-181. doi: 10.1177/1464884916688550.

15. Eco U. (1990). A Guide to the Neo-Television of the 1980s. In: Z. G. Baranski \& R. Lumley (Eds), Culture and Conflict in Postwar Italy (pp. 245-255). London: Macmillan.

16. Fortner, R., Snesareva, A. \& Tsitovich, K. (2014). Media, Civil Society, and the Public Sphere. History and Current Thinking. In R. Fortner \& P. Fackler (Eds.), The Handbook of Media and Mass Communication Theory (pp. 314-332). USA: John Wiley \& Sons.

17. Fuchs, C. (2009). Information and Communication Technologies Society: A Contribution to the Critique of the Political Economy of the Internet. European Journal of Communication, 24(1), 69-87. doi: 10.1177/0267323108098947.

18. Ge, Y. (2016). Sensationalism in media discourse: A genre-based analysis of Chinese legal news reports. Discourse \& Communication, 10(1), 22-39. doi: 10.1177/ 1750481315602395.

19. Habermas, J. (1974). The public sphere: an encyclopedia article. New German Critique, 3, 49-55.

20. Habermas, J. (1989). The structural transformation of the public sphere. An inquiry into a category of Bourgeois society. Cambridge, MA: MIT Press.

21. Hendricks, P., Nuijten, K. \& Beentjies, J. (2005). News in an Age of Competition: The Case of Sensationalism in Dutch Television News, 1995-2001. Journal of Broadcasting E Electronic Media, 49(3), 282-295. doi: 10.1207/s15506878jobem4903_2.

22. Herman, E. \& Chomsky, N. (1988). Manufacturing Consent: The Political Economy of the Mass Media. New York: Pantheon Books.

23. Hjarvard, S. (2012). The study of news production. In K. Bruhn (Ed.), A handbook of media and communication research: Qualitative and quantitative methodologies (2nd ed.) (pp. 87-105). London: Routledge. 
24. Lipovetsky, G. \& Serroy, J. (2008). La Culture-monde. Réponse à une société désorientée. Paris: Odile Jacob.

25. Littlejohn, S. \& Foss, K. (2009). Encyclopedia of Communication Theory. London: SAGE Publications.

26. Manning, N. \& Holmes, M. (2014) Political Emotions: A Role for Feelings of Affinity in Citizens' (Dis)Engagements with Electoral Politics? Sociology, 48(4), 698-714. doi: 10.1177/0038038513500103.

27. Martín Serrano, M. (2004). La reproducción social de la comunicación (3rd ed). Madrid: Alianza.

28. McManus, J. (1994). Market-driven Journalism. Let the Citizens Beware? Thousand Oaks, CA: SAGE.

29. Montero. E. \& Ferré-Pavia, C. (2017). Elementos de espectacularización en los informativos televisivos de 'prime time': el caso de 'Charlie Hebdo'. Observatorio $\left(\right.$ OBS $\left.^{*}\right)$ Journal, 035-060. doi: 10.15847/obsOBS1122017962.

30. Moreno-Díaz, J. \& Medina, E. (2017). La producción de concursos en las cadenas de televisión españolas: la espectacularización del formato (1990-2000). Comunicación y Medios, 26(35), 64-79. doi: 10.5354/0719-1529.2017.45111.

31. Mosco, V. (2009). The Political Economy of Communication (2nd ed). London: SAGE Publications.

32. Morales, J. (1971). Un marciano sin objeto / Cómo el poder de las noticias nos da noticias del poder. Santiago of Chile: Editorial Universitaria.

33. Shaw, D. L. \& McCombs, M. (1977). The emergence of American political issues: The agenda-setting function of the press. St. Paul, MN: West.

34. Simonson, P., Peck, J., Craig, R. \& Jackson, J. (2012). The History of Communication History from: The Handbook of Communication History. UK: Routledge.

35. Turow, J. (2009). Media Today: An Introduction to Mass Communication. New York: Routledge.

36. Valdivia, P. (2014). José Ricardo Morales de mar a mar: teatro transnacional, exilio y periferia. Biblioteca del Exilio. Sevilla: Renacimiento.

37. Van Aelst, P. \& Walgrave, S. (2016). Information and Arena. The Dual Function of the News Media for Political Elites. Journal of Communication, 66(3), 496-518. doi: 10.1111/jcom.12229. 


\section{Appendices}

The original extracts analyzed in this article, taken from José Ricardo Morales' play Cómo el poder de las noticias nos da noticias del poder (1971), are featured below.

\section{Extract 1:}

Llega EL MINISTRO. EL PERIODISTA se precipita hacia él. Se saludan afectuosamente. El grupo de artistas repite en sordina: Yo, yo, yo...

EL PERIODISTA: - ¡Señor Ministro!

EL MINISTRO: - ¡Amigo mío!

EL PERIODISTA: $-i$ Es cierto el rumor?

EL MINISTRO: (Después de pensarlo bien). - ¿Se refiere usted al vago murmullo que dice algo así como yo, yo, yo?

EL PERIODISTA: - Se escucha, en efecto.

EL MINISTRO: (Alarmado). - ¡Entonces, no se lo diga a nadie!

EL PERIODISTA: - Guardaré el secreto.

EL MINISTRO: - En nombre de la ética profesional.

EL PERIODISTA: - Cuente usted conmigo.

EL MINISTRO: - Es que desde niño escucho ese rumor que dice yo, yo, yo, yo, yo, yo. (Crece el murmullo de los artistas). ¿Lo oye?

EL PERIODISTA: - A lo mejor es un zumbido de sus oídos [...]

EL MINISTRO: - No. No. Si viene de mucho más adentro. El psiquiatra me dijo que se debe a una concomitancia de mi súper ego con el complejo hereditario paterno- materno por vía oral.

EL PERIODISTA: - Sin duda.

EL MINISTRO: - Pero no lo diga.

EL PERIODISTA: - ¿Cuándo un periodista no ha sabido guardar un secreto?

EL MINISTRO: - Tiene usted razón. Entonces no diga que también aspiro a la Presidencia.

EL PERIODISTA: (Sorprendido) - Así que es cierto el rumor...

EL MINISTRO: - ¿A cuál se refiere?

EL PERIODISTA: (Evadiéndose). - Los artistas dicen: "Yo, yo, yo".

EL MINISTRO: - Ah, bueno (Pausa). Entonces no diga que aspiro a convertir mi presidencia en monarquía anti- constitucional hereditaria.

EL PERIODISTA: - Soy mudo.

EL MINISTRO: (Decidiéndose). - ¡Le ofrezco mucho más! ¡Tendrá la primicia, la exclusividad!

EL PERIODISTA: (Exaltado). - Entonces, ¡hagamos noticia! Señor Ministro, soy todo oídos. (Morales, 1971, 74-75-76) 


\section{Extract 2:}

EL MINISTRO: - A condición de que aquello que le entre por el uno le salga por el otro. (Asiente EL PERIODISTA). ¿Sabe usted por qué acepté el Ministerio de Cultura?

EL PERIODISTA:(Asombrado). - ¿Me va a revelar el gran secreto que aún conmueve a la opinión pública?

EL MINISTRO: - En efecto. Piense usted conmigo: ¿Existe mejor preparación para la cultura que la agricultura?

EL PERIODISTA reflexiona. Mira al MINISTRO y sonríe. Sonrie EL MINISTRO. Ríe EL PERIODISTA. Se ríe EL MINISTRO. Una carcajada del PERIODISTA. Otra del MINISTRO. Prolongadas carcajadas del PERIODISTA y del MINISTRO que se contagian mutuamente. Decrece el carcajeo. Una sonrisa del PERIODISTA. Una del MINISTRO. Silencio.

EL MINISTRO: (Con cierto embarazo) - ¿Qué le parece el argumento?

EL PERIODISTA: - Irrefutable. La agricultura es la antesala de la cultura. ¿Y por eso cambió de la subsecretaría de transportes a la de economía doméstica, y de ésta a la de investigación nuclear, para pasar después a la de cuidados maternales?

EL MINISTRO: - Sí. Así me preparaba con rigor para los diferentes ministerios

EL PERIODISTA: - ¿Quiere explicarme cómo?

EL MINISTRO: - Muy sencillo. Porque la agricultura cabe cómodamente en la cultura y hasta se ahorran dos sílabas.

EL PERIODISTA: - ¡Fantástico! Así trabajan menos las mecanógrafas, los tipógrafos, los locutores y los agricultores... (Morales, 1971, 76)

\section{Extract 3:}

EL MINISTRO: - Usted me interpreta. Y la cultura incluye sin esfuerzo alguno a la puericultura, a la piscicultura, a la horticultura y a la escultura.

El coro de artistas exclama, sorprendido: ¡La escultura! Los artistas se precipitan hacia EL MINISTRO.

EL ARTISTA GORDO: - ¿Hablaban de escultura?

EL PERIODISTA: - El señor Ministro acaba de citarla.

EL ARTISTA FLACO: - No olviden que soy premio de la Bienal a cuadros de Venecia.

EL ARTISTA ALTO: (Quitándole la palabra). - Tengo mención honrosa de mis dos apellidos en Sao Paulo.

EL ARTISTA GORDO: - Soy primera medalla de arte religioso en Lourdes y en Fátima. $[\ldots]$

EL MINISTRO: - Diga, diga.

EL ARTISTA BAJO: - Y así sucesivamente. 
EL MINISTRO: - ¿Por qué no describe sus premios?

EL ARTISTA BAJO: - Mi modestia me impide decirle que no tengo premios.

EL MINISTRO: - ¿Cómo es posible?

EL ARTISTA BAJO: - Como lo oye.

EL MINISTRO: (Admirado). - ¡Un artista sin premios!

EL ARTISTA BAJO: - ¡El único!

EL MINISTRO: - ¡Un ser excepcional! ¡El gran incomprendido! Yo le prometo reparar la injusticia de inmediato. Constituyamos el jurado: el Ministro de Cultura, un representante de la prensa y un delegado de los artistas. (Morales, 1971, 78). 